Pedagogik Jurnal Pendidikan, Maret 2014, Volume 9 Nomor 1, ( $70-79$ )

\title{
LATIHAN RELAKSASI UNTUK MENGURANGI GEJALA INSOMNIA
}

\author{
Oleh : Esty Aryani Safithry *
}

\begin{abstract}
Abstrak
Kekurangan tidur dapat menyebabkan gangguan mood, emosi, konsentrasi dan menimbulkan malas. Latihan relaksasi dapat digunakan untuk mengurangi gejala insomnia, terapi ini merupakan bentuk terapi psikologis yang mendasarkan pada teori-teori behavioris.

Subyek penelitian adalah mahasiswa UM Palangkaraya. Jenis penelitian adalah studi kasus. Hasil penelitian menunjukkan bahwa terapi ini dapat menurunkan gejala insomnia, yang ditandai menurunnya tingkat ketegangan di saat akan maupun setelah tidur,saat terbangun pikiran menjadi lebih segar. Subjek mampu melaksanakan latihan relaksasi secara mandiri.
\end{abstract}

\section{Kata Kunci : Latihan Relaksasi, Insomnia}

\section{PENDAHULUAN}

Tidur adalah suatu fenomena biologis yang terkait dengan irama alam semesta, irama sirkadian yang bersiklus 24 jam, terbit dan terbenamnya matahari, waktu malam dan siang hari, tidur merupakan kebutuhan manusia yang teratur dan berulang untuk menghilangkan kelelahan jasmani dan kelelahan mental (Panteri, 2009).

Istirahat tidur dalam waktu $6-7$ jam sehari akan memberi kualitas tidur yang baik dan memberi pengaruh positif terhadap tubuh ketika bangun atau beranjak dari tidur maka tubuh akan terasa segar dan lebih baik serta membuat tubuh siap kembali untuk melakukan aktivitas dalam kesehariannya.

Tidur merupakan bagian hidup manusia yang memiliki porsi banyak, ratarata hampir seperempat hingga sepertiga waktu digunakan untuk tidur. Tidur merupakan kebutuhan bukan suatu keadaan istirahat yang tidak bermanfaat, tidur merupakan proses yang diperlukan oleh manusia untuk pembentukan sel-sel tubuh yang baru, perbaikan sel-sel tubuh yang rusak (natural healing mechanism), memberi waktu organ tubuh untuk beristirahat maupun untuk menjaga keseimbangan metabolisme dan biokimiawi tubuh. Mass, 2012).

Pada jurnal Psikiatri mengenai insomnia, menyebutkan bahwa orang dewasa di Amerika sebanyak 49\% menderita gangguan insomnia dan beberapa gangguan lain yang berkaitan dengan tidur (Mass 2009). Sedangkan penelitian yang dilakukan oleh di Jepang disebutkan $29 \%$ responden tidur kurang dari 6 jam, $23 \%$ merasa kekurangan dalam jam tidur $6 \%$ menggunakan obat tidur, kemudian $21 \%$ memiliki prevalensi insomnia dan $15 \%$ kondisi mengantuk yang parah pada siang harinya. (Liu, 2000).

Survei epidemiologi yang dilakukan oleh Melinger (Morin, 2010. Lacks, 2010) menunjukkan bahwa $35 \%$ dari populasi diindikasikan mengalami insomnia selama satu tahun terakhir, dan $10 \%$ mengalami gangguan insomnia 6 bulan terakhir. Dari survei tersebut juga disimpulkan bahwa wanita, orang yang lebih dewasa, dan mereka yang memiliki sosial ekonomi yang rendah lebih banyak mengalami gangguan tidur.

Bila kebutuhan tidur tidak dapat terpenuhi dengan baik maka hal ini akan 
mengakibatkan adanya gangguan tidur. Macam gangguan tidur ini beraneka ragam. Diantaranya salah satu jenis gangguan tidur yang paling umum terjadi adalah insomnia.

Kesulitan tidur atau insomnia adalah keluhan tentang kurangnya kualitas tidur yang disebabkan oleh satu dari; sulit memasuki tidur, sering terbangun malam kemudian kesulitan untuk kembali tidur, bangun terlalu pagi, dan tidur yang tidak nyenyak. Insomnia tidak disebabkan oleh sedikitnya seseorang tidur, karena setiap orang memiliki jumlah jam tidur sendirisendiri. Tapi yang menjadi penekanan adalah akibat yang ditimbulkan oleh kurangnya tidur pada malam hari seperti kelelahan, kurang gairah, dan kesulitan berkonsentrasi ketika beraktivitas.

Menurut National Institute of Health (2000) Insomnia atau gangguan sulit tidur dibagi menjadi tiga yaitu insomnia sementara (intermittent) terjadi bila gejala muncul dalam beberapa malam saja. Insomnia jangka pendek (transient) bila gejala muncul secara mendadak tidak sampai berhari-hari, kemudian insmonia kronis (Chronic) gejala susah tidur yang parah dan biasanya disebabkan oleh adanya gangguan kejiwaan. Penyebab insomnia intermitten dan transient antara lain stress, kebisingan, udara yang terlalu dingin atau terlalu panas, tidur tidak di tempat biasanya, berubahnya jadwal tidur dan efek samping dari obat-obatan. Sedangkan insomnia yang kronik disebabkan oleh beberapa faktor

Terutama secara fisik dan mental disorder. Secara lebih rinci Soresso (tanpa tahun) membagi penyebab munculnya gangguan tidur menjadi 6 yaitu :

1. Farmakologis, pemakaian obat-obatan 2. Medis, misalnya sakit kepala, kesulitan bernafas

3. Genetik, memiliki darah keturunan dari penderita insomnia yang parah

4. Konsumsi tembakau atau alkohol

5. Psikiatris, misalnya gangguan emosi, kecemasan, schizoprenia, somatoform

6. Gangguan psikologis, setelah mengalami pengalaman traumatis, ditinggal orang yang

dicintai dan frustrasi kesulitan mencoba untuk tidur.

Penyembuhan terhadap insomnia tergantung dari penyebab yang menimbulkan insomnia. Bila penyebabnya adalah kebiasaan yang salah atau lingkungan yang kurang kondusif untuk tidur maka terapi yang dilakukan adalah merubah kebiasaan dan lingkungannya. Sedangkan untuk penyebab psikologis maka konseling dan terapi relaksasi dapat digunakan untuk mengurangi gangguan sulit tidur, terapi ini merupakan bentuk terapi psikologis yang mendasarkan pada teori-teoribehavioris.

Goldfriend dan Trier (2009) melaporkan terapi relaksasi efektif untuk menurunkan kecemasan, metode yang digunakan sebagai self control coping skill. Jacobson (2010) melaporkan penurunan denyut nadi dan tekanan darah pada pasien dengan ansietas. Prawitasari (2009) melaporkan bahwa terapi relaksasi sangat efektif untuk pasien dengan kecemasan menyeluruh, kecemasan berbicara di muka umum. Dewi (2009) melaporkan latihan relaksasi mampu menurunkan ketegangan bagi para siswa sekolah penerbangan. Karyono dkk (1994) melaporkan bahwa relaksasi dapat menurunkan tekanan darah systolic dan diastolic pada pasien hipertensi. Purwaningsih dan Utami (2009) melaporkan keberhasilannya terapi relaksasi pada pasien dengan kecemasan berbicara di muka umum (phobia spesifik) dan pasien phobia sosial. Masih banyak penelitian lain yang menunjukkan 
efektifitas terapi relaksasi: pasien Insomnia, nyeri kepala, nyeri leher, dan banyak lagi.

Dasar pikiran relaksasi adalah sebagai berikut. Relakasasi merupakan pengaktifan dari saraf parasimpatetis yang menstimulasi turunnya semua fungsi yang dinaikkan oleh sistem saraf simpatetis, dan menstimulasi naiknya semua fungsi yang diturunkan oleh saraf simpatetis. Masing-masing saraf parasimpatetis dan simpatetis saling berpegaruh maka dengan bertambahnya salah satu aktivitas sistem yang satu akan menghambat atau menekan fungsi yang lain (Utami, 2009). Ketika seseorang mengalami gangguan tidur maka ada ketegangan pada otak dan otot sehingga dengan mengaktifkan saraf parasimpatetis dengan teknik relaksasi maka secara otomatis ketegangan berkurang sehingga seseorang akan mudah untuk masuk ke kondisi tidur. Berbagai macam bentuk relaksasi yang sudah ada adalah relaksasi otot, relaksasi kesadaran indera, relaksasi meditasi, yoga dan relaksasi hipnosa (utami, 2009).

Teknik relaksasi yang digunakan pada penelitian ini adalah relaksasi otot jenis Relaxation via Tension-Relaxation. Teknik ini Bertujuan mengurangi ketegangan dan atau kecemasan, dengan merelaksasikan atau melemaskan otot-otot badan. Individu di minta untuk menegangkan otot dengan ketegangan tertentu kemudian disuruh mengendorkan atau melemaskannya, antara ketegangan dan pengendoran individu diminta untuk merasakan perbedaannya, sampai mampu membedakan antara otot yang tegang dengan yang lemas.

Permasalahan penelitian yang dapat ditarik dari uraian di atas adalah apakah latihan relaksasi dapat berpengaruh terhadap penurunan gejala insomnia.

\section{METODE PENELITIAN Subyek Penelitian}

Subyek penelitian berjumlah 1 orang yang merupakan mahasiswa Universitas Muhammadiyah Palangkaraya Alasan dipilihnya mahasiswa UMP sebagai subyek penelitian adalah karena berdasarkan Survey dari Bimbingan dan Konseling UMP tahun 2014 di lingkungan mahasiswanya, persoalan gangguan tidur yang meliputi: baru bisa tidur sekitar jam 3 walaupun sudah mencoba tidur sejak jam 9 malam. Bahkan sering tidak tidur sama sekali. Walaupun subjek sudah bisa tertidur biasanya ia dapat terbangun sekitar 5 sampai 10 kali dan hampir tidak bisa tertidur kembali. Ia bisanya terbangun dengan perasaan deg-degan padahal ia tidak berminpi buruk, kadang ia juga berkeringat. padahal besok harinya klien harus bangun pagi dan melakukan segala aktifitas yang harus dikerjakan. Karena hampir tidak tidur membuat konsentrasi terganggu, sulit berkonsentrasi, gampang emosi, suka bingung sendiri.. Selain itu juga karena pertimbangan praktis bahwa Universitas Muhammadiyah Palangkaraya adalah tempat peneliti bekerja selama ini. Jumlah subyek dalam penelitian ini 1 orang. Jumlah subyek dalam penelitian ini yang berjumlah lebih dari satu bertujuan untuk mencapai validitas eksternal seperti yang ditulis oleh Kazdin (2009) bahwa validitas eksternal dari single case research bergantung pada replikasi sistematis mengenai efek terapi dari banyak klien.

\section{Rancangan Penelitian}

Penelitian ini dapat digolongkan dalam penelitian Single-case designs (Kazdin, 2009) atau Small $N$ - designs (Barker, Pistrang \& Elliot, 2006). Single case designs terdiri dari: (1) manipulasi eksperimental suatu treatmen yang lazim disebut single-case experimental designs 
dan (2) yang bersifat non-eksperimental dari suatu treatmen yang lazim disebut case study, meskipun garis yang tegas diantara kedua pendekatan itu tidaklah selalu jelas (Barker, Psitrang, \& Elliot, 2006).

Elemen desain yang digunakan dalam penelitian ini adalah $A B A$ design; di mana A adalah fase sebelum terapi, $\mathrm{B}$ adalah fase terapi atau intervensi yang kemudian dilanjutkan dengan fase tindak lanjut $\mathrm{A}$ (Kazdin, 2009).

\section{Metode Pengumpulan Data}

Wawancara dilakukan sebagai metode untuk melakukan asesmen pada tahap pra terapi, selama proses terapi, pasca terapi dan tindak lanjut. Wawancara pada saat praterapi dilakukan untuk mengetahui keadaan awal subyek. Wawancara dilakukan kepada subjek, dan orang-orang terdekat mereka. Wawancara ini bertujuan untuk menggali permasalahan seputar insomnia. Wawancara juga diperlukan dalam untuk memperkuat data dari skala yang telah diisi oleh subyek. Wawancara selama proses terapi (treatment) dilakukan untuk mengetahui apa yang dirasakan subyek, serta untuk mengetahui hambatan apa saja yang dirasakan oleh subyek, dan hal-hal lain yang berhubungan dengan treatment yang diberikan oleh peneliti. Wawancara saat pasca terapi dilakukan untuk mengetahui bagaimana progress atau perubahan yang dirasakan oleh subyek setelah perlakuan diberikan, sehingga dapat diketahui juga ada tidaknya pengaruh atau efek dari treatment tersebut. Pada tahap tindak lanjut wawancara dilakukan untuk mengetahui penurunan tingkat subyek setelah terapi dihentikan. Observasi dalam penelitian ini bersifat non partisipan yang berarti peneliti tidak terlibat dalam aktivitas yang diamatinya (Poerwandari, 2001). Observasi dilakukan oleh peneliti dan subyek sendiri terhadap tingkah laku yang menjadi fokus terapi. Observasi oleh peneliti terutama dilakukan pada saat pelaksanaan relaksasi. Observasi yang dilakukan oleh subyek adalah dalam bentuk self monitoring pada proses terapi dan pada tahap tindak lanjut. Menurut Martin \& Pear (2003), self-monitoring adalah observasi langsung yang dilakukan oleh klien sendiri terhadap tingkah lakunya. Dalam penelitian ini self report dibuat oleh subyek pada saat pelaksanaan relaksasi, dan pada tahap tindak lanjut. Kuesioner yang dipakai dalam penelitian ini adalah kuesioner riwayat hidup yang memberikan data demografi seperti tempat tinggal, status perkawinan, agama dan latar belakang keluarga, kesehatan, riwayat pendidikan dan sebagainya (Martin \& Pear, 2003). Kuesioner riwayat hidup diberikan kepada subyek untuk mendapatkan gambaran mengenai diri pribadi subyek secara menyeluruh dan hal-hal yang perlu digali lebih lanjut akan diperdalam melalui wawancara. Kuesioner kedua adalah berupa form evaluasi yang meliputi: (1) Penilaian subyek terhadap dirinya sendiri setelah mengikuti terapi; (2) Penilaian subyek terhadap terapi itu sendiri. Kuesioner evaluasi ini sebagai data pelengkap dari wawancara pada tahap pasca terapi, yaitu saat dilakukannya evaluasi setelah terapi dihentikan. Skala perlu diberikan untuk memperkuat data yang telah didapat, sehingga peneliti dapat memperoleh subyek yang tepat untuk terapi ini.

\section{Prosedur Intervensi \\ Tahap praterapi}

Tahap pra-terapi ini dibagi menjadi 1 kali pertemuan, kegiatanya adalah memberikan pengetahuan mengenai insomnia kepada subjek dan mengisi skala insomnia 


\section{Saat terapi}

Latihan relaksasi yang dipakai dalam penelitian ini adalah relaksasi progresif yang telah disusun oleh Soewondo (2003).

Inti dari latihan relaksasi progresif ini adalah: (1) Belajar untuk menegangkan dan mengendurkan bermacam-macam kelompok otot dan (2) Belajar untuk memperhatikan perbedaan antara rasa tegang dan rileks.

Kumpulan otot yang akan ditegangkan nanti adalah:

a) Tangan dan lengan kanan

b) Tangan dan lengan kiri

c) Kaki, paha, jari-jari kaki kanan

d) Kaki, paha, jari-jari kaki kiri

e) Dahi

f) Mata

g) Bibir, gigi, lidah, rahang

h) Dada

i) Leher

Latihan relaksasi ini sudah mulai diajarkan kepada klien sejak pertemuan pertama dengan peneliti (sesi perkenalan). Alasannya adalah bahwa latihan relaksasi adalah suatu keterampilan ; yang berarti akan memberikan hasil yang lebih optimal apabila banyak dilatihkan dan dipraktekkan. Oleh karena itu semakin cepat subyek diperkenalkan latihan relaksasi, maka subyek memiliki kesempatan untuk dapat segera berlatih dan mempraktekkannya di berbagai kesempatan dan juga di rumah. Selanjutnya, latihan relaksasi ini akan selalu diberikan pada awal setiap sesi pertemuan dengan peneliti. Dengan "mengajak" subyek berlatih relaksasi terlebih dahulu sebelum suatu sesi terapi dimulai, subyek akan merasa lebih rileks dan nyaman, dengan harapan subyek akan dapat mengikuti sesi treatmen dengan lebih baik. Hal ini sejalan dengan apa yang disampaikan oleh Goldfried dan Davison (2006) yaitu membuat klien merasa rileks dan nyaman dengan memberikan latihan relaksasi sebelum konseling/terapi dimulai dan sebelum melakukan restrukturisasi kognitif akan sangat membantu klien. (Nevid, 2005).

\section{Tahap pascaterapi}

Kegiatan paska terapi ini kegiatanya adalah mengidentifikasi tingkat insomnia, serta pemberian lembar evaluasi yang berisi apa saja perubahan yang telah mereka rasakan.

\section{Tahap follow up}

Tahap ini dilakukan untuk melihat apakah hasil dari proses terapi bisa bertahan permanen, meskipun sudah tidak ada lagi penaganan. Tahap ini akan dilakukan 2 minggu setelah proses terapi berakhir.

\section{Metode Penilaian dan Pengukuran}

Penilaian dan pengukuran dilakukan sebelum treatmen (pra terapi), selama terapi berlangsung, segera setelah keseluruhan terapi selesai diberikan (pasca terapi), dan terakhir pada tahap tindak lanjut (setelah terapi dihentikan).

Penilaian selama terapi dilakukan terus menerus pada setiap sesi selama terapi berlangsung dimulai setelah teknik relaksasi diberikan. Penilaian setelah terapi (pasca terapi) dilakukan segera setelah keseluruhan terapi selesai diberikan. Sedangkan penilaian dan pengukuran pada tahap tindak lanjut dilakukan dua minggu setelah pasca terapi (tindak lanjut ke-1) dan satu bulan setelah pasca terapi (tindak lanjut ke-2). Penilaian dan pengukuran pada tahap tindak lanjut dilakukan untuk mengetahui apakah ada pengurangan gejala subyek yang terjadi selama terapi berlangsung relatif menetap setelah terapi dihentikan. 


\section{HASIL PENELITIAN}

Hasil dan analisis terapi keseluruhan subjek

Berdasarkan hasil terapi dapat diketahui bahwa subjek mengalami perubahan yang cukup berarti setelah beberapa proses terapi. Perubahan tersebut terdiri dari penurunan gejala insomnia.

\section{Latihan relaksasi}

a. Sebelum latihan

Klien merasakan badanya sering kali pegal terutama setelah ia olahraga futsal pada malam hari. Kadang ia tidur dalam keadaan gelisah dan merasa belum puas tidur. Jika ada suara ribut, klien mudah sekali terbangun dan jika ingin tidur lagi sangat sulit bahkan tidak bisa tidur lagi walaupun saat itu masih pukul 03.00 pagi.

b. Saat latihan

Kendala yang dihadapi Klien adalah pertama kali klien sering merasa kesemutan, sulitnya untuk memulai latihan di waktu yang tepat karena keadaan sedang ramai dan sulit berkonsentrasi karena memikirkan halhal lain.

Faktor pendukung keberhasilan klien dalam melaksanakan latihan relaksasi adalah kemauan klien yang tinggi walaupunkeadaan fisik klien yang sedang kurang sehat namun pada akhirnya latihan klien berjalan dengan lancar baik latihan bersama terapis atau latihan secara mandiri

c. Setelah latihan

Setelah melakukan latihan relaksasi, klien merasakan perubahan yang cukup signifikan, perasaan klien menjadi lebih tenang dan rileks dari pada sebelumnya.
Kemudian selama 1 minggu klien dapat menerapkan latihan relaksasi sendiri, keluhan insomnia klien berkurang. Sebelum latihan keluhan sulit tidur hampir 5-6 kali seminggu setelah selesai semua sesi keluhan hanya 1-2 kali saja. Selain itu badan klien menjadi lebih ringan dan keluhan nyeri berkurang

Selain itu ada beberapa manfaat dari latihan relaksasi yang didapat klien antara lain:

1) Saat klien periksa ke dokter, tekanan darah klien berkurang dari 140/90 menjadi 110/70

2) Perasaan cemas akibat tidak bisa tidur menjadi berkurang

3) Mengurangi perilaku tertentu yang sering terjadi selama periode stres seperti mengurangi jumlah rokok yang dihisap, konsumsi kopi, pemakaian obat tidur dan makan yang berlebihan

\section{Kemajuan Hasil Terapi}

Sebelum di berikan terapi, klien mengisi kuesioner untuk mengetahui tingkat insomnia sebelum dan sesudah diberikan terapi. Sebelum di berikan terapi, tingkat insomnia klien masuk dalam kategori berat dengan skor 60 kemudian setelah dilakukan 3 kali latihan relaksasi dan klien mempraktekanya setiap hari sebelum tidur dan munculnya alternatif pemikiran positif,

\section{Follow Up}

Setelah klien diberikan pelatihan relaksasi selama 7 hari dan restrukturisasi kognitif maka kemudian klien memiliki keterampilan dalam mengurangi insomnianya. Untuk itu klien dibiarkan selama 2 minggu tanpa diberikan perlakuan.

Klien dapat merasakan bahwa latihan relaksasi dan pemikiran positif yang 
Pedagogik Jurnal Pendidikan, Maret 2014, Volume 9 Nomor 1, ( $70-79)$

berulangkali ia terapkan sendiri sangat up didapat skor kuesioner 37 masih dalam berguna untuk mengurangi keluhan kategori ringan. Perbandingan tingkat insomnia klien insomnia saat sebelum perlakuan, sesudah

Saat klien diberikan kuesioner untuk perlakuan dan setelah follow up seperti mengetahui tingkat insomnia setelah folow grafik di di bawah ini:

\section{Grafik tingkat insomnia}

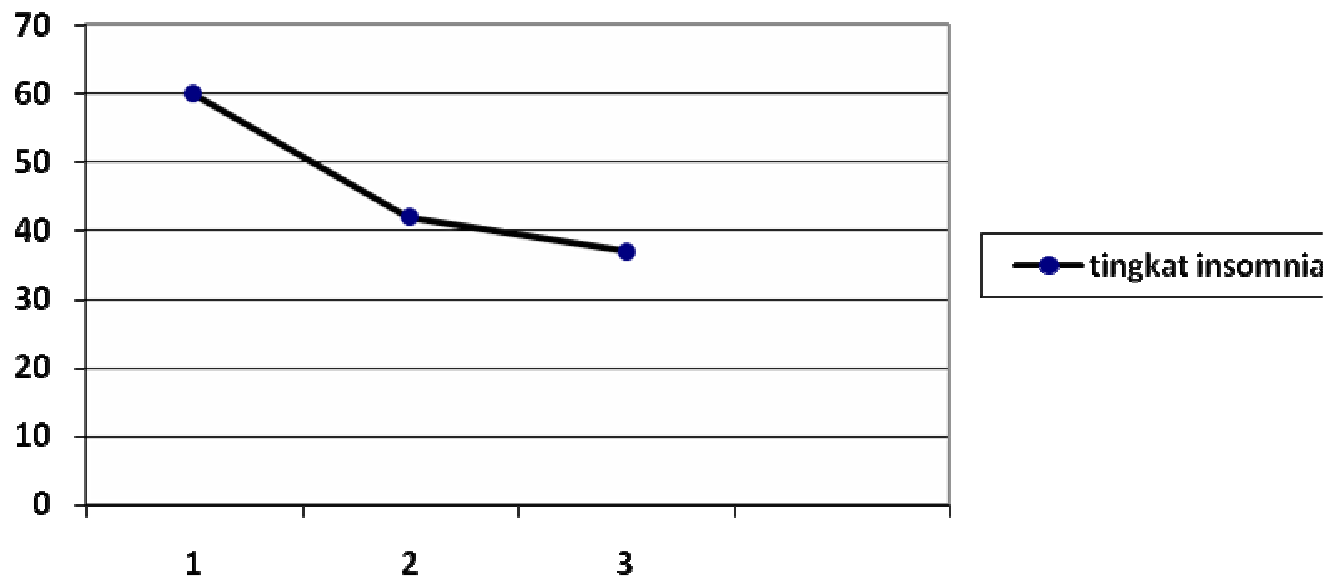

Dapat dilihat dari grafik diatas sebelum perlakuan, insomnia klien termasuk dalam kategori berat dengan skor 60 kemudian setelah proses terapi tingkat insomnia klien menurun menjadi ringan dengan skor 42 .
Setelah tidak diberi perlakuan selama satu minggu tingkat insomnia klien masih ringan namun skor turun menjadi 37.

Untuk melihat kemajuna klien per hari dapat di lihat pada bagan berikut :

1. Sebelum proses terapi

\begin{tabular}{|l||l||l||}
\hline Hari & Ada keluhan & Tidak ada keluhan \\
\hline \hline Senin & & \\
\hline \hline Selasa & & \\
\hline \hline Rabu & & \\
\hline \hline Kamis & & \\
\hline \hline Jumat & & \\
\hline \hline Sabtu & & \\
\hline \hline Minggu & & \\
\hline
\end{tabular}


Pedagogik Jurnal Pendidikan, Maret 2014, Volume 9 Nomor 1, (70-79)

2. Setelah proses terapi

\begin{tabular}{|c|c|c|}
\hline Hari & Ada keluhan & Tidak ada keluhan \\
\hline Senin & & \\
\hline Selasa & & \\
\hline Rabu & & \\
\hline Kamis & & \\
\hline Jumat & & \\
\hline Sabtu & & \\
\hline Minggu & & \\
\hline
\end{tabular}

3. Setelah follow up

\begin{tabular}{|c|c|c|}
\hline Hari & Ada keluhan & Tidak ada keluhan \\
\hline Senin & & \\
\hline Selasa & & \\
\hline Rabu & & \\
\hline Kamis & & \\
\hline Jumat & & \\
\hline Sabtu & & \\
\hline Minggu & & \\
\hline
\end{tabular}

\section{PEMBAHASAN}

Klien yang mengeluhkan kesulitan tidur dan kurangnya kualitas tidur membuat kegiatan klien disiang hari menjadi terganggu. Saat klien berfikir bahwa jika tidurnya terganggu maka keesokan harinya ia akan mangantuk dan kesulitan untuk beraktifitas, ia juga berfikir baha ia harus tidur 7-8 jam semalam agar kualitas tidurnya tetap baik. Pikiran-pikiran tersebut mengganggu klien saat ia akan tidur. Pendekatan dengan penanganan behavioral telah menghasilkan manfaat yang penting dalam menangani insomnia kronis, seperti yang diukur baik dalam pengurangan sejumlah besar waktu yang dibutuhkan untuk dapat tertidur dan jumlah terjaga pada malam hari maupun dalam peningakatan kualitas tidur. Pada sebuah studi terkini, dua dari tiga partisipan penanganan mampu untuk tidur selama 30 menit istirahat. Ahli tidur yakin bahwa relaksasi sama efektifnya dengan obat-pbat tidur dalam menangani insomnia untuk jangka waktupendek dan lebih efektif untuk jangka panjang (Nevid, 2007).

Teknik relaksasi menekankan pada jangka pendek dan berfokus pada penurunan langsung kondisi fisiologis yang timbul, memodifikasi kebiasaan tidur yang maladaftif dan mengubah pemikiran yang disfungsional. Relaksasi otot progresif dikenal sebagai pengobatan alternatif insomnia yang efektif untuk menggantikan obat tidur, bahkan bagi orang yang menderita masalah insomnia kronis.

Terapis behavioral biasanya menggunakan beberapa kombinasi dari beberapa teknik seperti latihan relaksasi dan konseling. Konseling individual berfokus pada keyakinan klien bahwa kegagalan untuk dapat tidur nyenyak akan mengakibatkan, konsekuensi yang tidak mengenakan, bahkan membawa bencana, di 
keesokan harinya dapat mengurangi kemungkinan untuk dapat tidur karena ada peningkatan tingkat kecemasan dan dapat membuat seseorang gagal untuk mencoba tidur. Padahal kebanyakan orang lain baikbaik saja jika mereka hanya tidur 3 atau 4 jam.

Klien diinstruksikan untuk membatasi waktu yang dihabiskan di tempat tidur untuk mencoba tidur hanya dalam waktu 10-20 menit. Jika klien masih tidak dapat tidur juga pada waktu yang diperkirakan, klien diinstruksikan untuk meninggalkan tempat tidur dan pergi keruangan lain untuk membangun kerangka berfikir yang santai sebelum tidur seperti memparaktekan latihan relaksasi.

Relaksasi otot progresif dapat dilakukan selama 20-30 menit, satu kali sehari secara teratur selama satu minggu. Hal tersebut di atas sesuai dengan teori yang dikemukakan oleh Edmund Jacobson (2010) dalam Davis (2010) bahwa latihan relaksasi otot progresif yang dilaksanakan 20-30 menit, satu kali sehari secara teratur selama satu minggu cukup efektif dalam menurunkan insomnia.

Ketika Klien mengalami ketegangan emosional maka beberapa otot akan mengalami ketegangan sehingga mengaktifkan sistem saraf simpatis. Pada kondisi stres, secara fisiologis tubuh akan mengalami respon yang dinamakan respon fight or flight. Respon ini memerlukan energi yang cepat, sehingga hati melepaskan lebih banyak glukosa untuk menjadi bahan bakar otot, dan terjadi pula pelepasan hormon yang menstimulasi perubahan lemak dan protein menjadi gula. Metabolisme tubuh meningkat sebagai persiapan untuk pemakaian energi pada tindakan fisik. Kecepatan jantung, tekanan darah, dan kecepatan pernapasan meningkat, serta otot menjadi tegang. Pada saat yang sama aktivitas tertentu yang tidak diperlukan (seperti pencernaan) dihentikan. Sebagian besar perubahan fisiologis tersebut terjadi akibat aktivitas dua sistem neuroendokrin yang dikendalikan oleh hipotalamus yaitu sistem simpatis dan sistem kortek adrenal.

Aktifnya saraf simpatis membuat klien tidak dapat santai atau relaks sehingga tidak dapat memunculkan rasa kantuk. Melalui latihan relaksasi klen dilatih untuk dapat memunculkan respon relaksasi sehingga dapat mencapai keadaan tenang. Respon relaksasi ini terjadi melalui penurunan bermakna dari kebutuhan zat oksigen oleh tubuh, yang selanjutnya aliran darah akan lancar, neurotransmiter penenang akan dilepaskan, sistem saraf akan bekerja secara baik otot-otot tubuh yang relaks menimbulkan perasaan tenang dan nyaman. (Benson, 2000 : Purwanto, 2007). Kondisi rileks yang dirasakan tersebut dikarenakan latihan relaksasi dapat memberikan pemijatan halus pada berbagai kelenjar-kelenjar pada tubuh, menurunkan produksi kortisol dalam darah, mengembalikan pengeluaran hormon yang secukupnya sehingga memberi keseimbangan emosi dan ketenangan pikiran

Selain hal di atas, Latihan relaksasi otot progresif cukup efektif untuk memperpendek waktu dari mulai merebahkan hingga tertidur dan mudah memasuki tidur. Hal ini membuktikan bahwa relaksasi otot progresif yang dilakukan dapat membuat tubuh lebih relaks sehingga kesulitan ketika mengawali tidur dapat diatasi dengan treatmen ini. Hal yang sama diperkuat oleh teori Edmund Jacobson (2010) bahwa teknik relaksasi progresif memberi respons terhadap ketegangan, respon tersebut menyebabkan perubahan yang dapat mengontrol aktivitas 
sistem saraf otonom berupa pengurangan fungsi oksigen, frekuensi nafas, denyut nadi, ketegangan otot, tekanan darah, serta gelombang alfa dalam otak sehingga mudah untuk tidur.

Perangsangan sistem saraf otonom juga memainkan peranan yang sangat penting dalam pemeliharaan tekanan arteriol dengan pengaruhnya pada cardiac output dan derajat konstriksi dari resistensi (arteriol) serta kapasitasi (venul dan venula) pembuluh darah yang mengakibatkan resistensi perifer menurun dan tekanan darah juga menurun (Purba, 2002). Hal ini dibuktikan pada saat sesudah latihan klien yang mengalami penurunan tekanan darah dari $140 / 90 \mathrm{mmHg}$ menjadi $110 / 70 \mathrm{mmHg}$ karena latihan relaksasi tersebut dilakukan secara berulang-ulang.

pelatihan relaksasi dapat memunculkan keadaan tenang dan rileks dimana pikiran yang mengganggu pada klien dapat ia kurangi kemudian membantunya untuk rileks, karena selain merilekskan pikiran perpaduan terapi ini juga dapat merilekskan otot-otot yang tegang. Konsistensi dari latihan relaksasi otot progresif selama satu minggu secara teratur ini membuktikan bahwa latihan relaksasi otot progresif mempunyai hasil yang bagus untuk menurunkan keluhan insomnia. Selain faktor tersebut, terapis memperkirakan penurunan tingkat insomnia disebabkan oleh kondusifnya lingkungan ketika melakukan latihan relaksasi otot progresif dan sering dipraktekannya lagi latihan tersebut ketika klien terbangun dari tidur.

\section{KESIMPULAN}

Berdasarkan hasil penelitian dapat diketahui bahawa penerapan latihan relaksasi yang selama 8 kali pertemuan dapat gejala insomnia. Teknik yang digunakan adalah latihan relaksasi otot progresif. Adapun perubahan-perubahan yang dialami subjek setelah mengikuti proses terapi adalah sebagai berikut :

1. Frekuensi gangguan tidur mengalami penurunan selama menjalani proses terapi. Penerapan latihan relaksasi sangat membantu dalam mengurangi tingkat kecemasan.

2. Munculnya tingkahlaku positif dimana subjek sudah tidak lagi mengalami gejala insomnia dan mampu menerapkan latihan relaksasi secara mandiri

\section{DAFTAR PUSTAKA}

Benson, H.M.D. 2000. Dasar-dasar Respon Relaksasi: Bagaimana menggabungkan respon Relaksasi dengan Keyakinan Pribadi Anda. Bandung. Mizan

Cottone, R.R. (2010). Theories and Paradigms of Counseling and Psychoterapy. Boston: Allyn \& Bacon.

Craighead, L.W., Craighead, W.E., Kazdin, A.E., \& Mahoney, M.J. (2004). Cognitive And Behavioral Interventions. Boston: Allyn and Bacon.

Davis, M, Eshelman, E.R dan Matthew Mckay. 2010. Panduan Relaksasi dan Reduksi Stres Edisi III. Alih Bahasa: Budi Ana Keliat dan Achir Yani. Jakarta. Penerbit Buku Kedokteran EGC

Diagnostic And Statistical Manual of Mental Disorders. Fourth Edition (2000). Washington, DC: American Psychiatric Association. 
Pedagogik Jurnal Pendidikan, Maret 2014, Volume 9 Nomor 1, ( $70-79)$

Goldfried, M.R., \& Davison, G.C. (2006). Clinical Behavior Therapy. New York: Holt, Rinehart and Winston.

Goldfried, M.R. and Trier, C.S., (2004). Effectivesness of Relaxation as an Active Coping Skill. Journal of Abnormal Psychology, 83, 4, 348-355

Holmes, D. S. (2007). Abnormal Psychology. Third Edition. New York: Addison - Wesley Educational Publisher Inc.

Kazdin, A.E. (2009). Methodological Issues \& Strategies in Clinical Research. Washington DC : American Psychological Association.

Jacobson, L., Sapolsky, R. Helm,C. Newport, DJ. Bonsall, R., Mileer, AH., Nemeroff,CB. (2004) Journal of Positive Psychology and the Cognitive Tradition for Sleep Hygine, 19, 6-9

Lacks. P., Morin. C,. 2010. Recent Advances in the Assessment and Treatment of Insomnia. Journal of Consulting and Clinical Psychology Vol 60. No. 4, 586-594.

Liu. Xianchen et al. 2000. Sleep Loss and Day Time Sleepiness in the General Adult Population of Japan Psychiatric research 93 1-11

Martin, G., \& Pear, J. (2003). Behavior Modification What It Is And How To Do It. Seventh Edition. New Jersey: Prentice Hall, Inc.

Nevid, J.S., Rathus, S.A., \& Green, E.B. (2005). Abnormal Psychology In Changing World. New Jersey: Prentice Hall.

Panteri, IGP. 2009. Gangguan Tidur Insomnia dan Terapinya Suatu Kajian Pustaka.

Majalah Ilmiah Unud th xx No 37

Poerwandari, K. (2001). Pendekatan Kualitatif untuk Penelitian Perilaku Manusia. Jakarta: Lembaga Pengembangan Sarana Pengukuran dan Pendidikan Psikologi (LPSP3) Fakultas Psikologi Universitas Indonesia.

Prawitasari, J.E. (2009). Behavior Therapy In Indonesia. Dalam Oei, T.P.S., Behavior Therapy and Cognitive Behavior Therapy in Asia (hlm 81 - 96). Brisbane: Edumedia Pty Ltd.

Sarason, I.G., \& Sarason, B.R. (2009). Abnormal Psychology. The Problem of Maladaptive Behavior. Ninth Edition. New Jersey: Prentice-Hall, Inc.

Soewondo, S. (2003). Modul Latihan Relaksasi. Jakarta: Lembaga Psikologi Terapan Universitas Indonesia.

Soresso, D. (tanpa tahun) Produced by The Sleep Research Laboratory. www.internethealthlibrary.com. Chicago :the University of Chicago.

* Esty Aryani Safithry, M.Psi Dosen FKIP Universitas Muhammadiyah Palangkaraya 